\title{
REFLEXÕES CRÍTICAS SOBRE O VOTO EM BRANCO E SOBRE VOTO NULO NO BRASIL
}

\author{
CRITICAL REFLECTIONS ON THE BLANK VOTE AND ON THE NULL VOTE IN \\ BRAZIL
}

Felipe Chiarello

Mestre e Doutor em Direito pela Pontifícia Universidade Católica de São Paulo, membro do Conselho Técnico Científico, do Conselho Superior e do Comitê da Área do Direito da CAPES-MEC, Atualmente é Diretor da Faculdade de Direito da Universidade Presbiteriana Mackenzie e Professor do Programa de Mestrado e Doutorado em Direito Político e Econômico, Membro da Comissão de Revisão da Matriz Curricular da Graduação em Direito no Brasil (Convidado Externo CNE ), Membro do Comitê da Área do Direito no Programa SciELO/ FAPESP, membro Titular da Academia Paulista de Letras Jurídicas e Secretário Adjunto do CONPEDI. E-mail: felipechiarello@gmail.com

Leandro Sarai

Doutor e Mestre em Direito Político e Econômico e Especialista em Direito Empresarial pela Universidade Presbiteriana Mackenzie. Advogado Público Federal. E-mail: leandrosarai@yahoo.com.br

Recebido em: 26/08/2017

Aprovado em: 13/11/2017

Doi: $10.5585 /$ rdb.v18i7.772

Resumo: Traz um panorama do ordenamento vigente para os votos em branco e para os votos nulos nas eleições proporcionais. Demonstra que nessas eleições, ambos os votos são equivalentes na prática. Realiza, com base nesse panorama, análise casuística de exemplos práticos para constatar as repercussões causadas pela alteração no número de votos brancos, ora não os computando, ora os considerando. Constata que é necessário um número expressivo de votos em branco ou nulos para haver alterações significativas no resultado das eleições. Apura que a realização de novas eleições em razão do número de votos em branco ou nulos é improvável, ante a exigência números extremos de votos desse tipo. Realiza a mesma análise para as eleições majoritárias. Conclui não haver uma maneira de negar um candidato pelo voto. Infere haver uma contradição ao exigir o comparecimento do eleitor e desconsiderar seu voto, caso seja nulo ou branco.

Palavras-chave: Voto em branco - Voto Nulo - Eleições Proporcionais - Eleições Majoritárias - Análise Casuística.

ABSTRACT: It provides an overview of the current legal system for blank votes and null votes in proportional elections. It demonstrates that in these elections, both votes are equivalent in practice. Based on this overview, it performs casuistic tests to observe the effects caused by the change in the number of blank votes, first disregarding these votes in the counting, then counting them. It notes that a significant number of blank or null votes is necessary to cause significant changes in the outcome of elections. It verifies that is unlikely that new elections occur because 
of the number of blank or spoiled votes, given the requirement extreme numbers of votes that type. It performs the same analysis for statewide elections. It concludes there is not a way to deny a candidate by the vote. It infers there is a contradiction in requiring voter turnout and disregard its vote, if null or blank.

Keywords: blank vote - null vote - proportional elections - majoritarian elections - casuistic.

SUMÁRIO: Introdução. 1 O voto em branco e o voto nulo nas regras das eleições proporcionais. 1.1 Análise prática 1.1.1 Primeiro exemplo. 1.1.2 Segundo exemplo. 1.1.3 Terceiro exemplo. 1.1.4 Quarto exemplo. 1.1.5 Quinto exemplo. 1.1.6 Sexto exemplo. 1.1.7 Conclusões sobre o voto em branco e o voto nulo nas eleições proporcionais. $2 \mathrm{O}$ voto em branco e o voto nulo nas regras das eleições majoritárias. 3 Reflexões críticas. Conclusão. Referências Bibliográficas.

\section{INTRODUÇÃO}

Recentemente uma empresa veiculou uma propaganda em que uma aeromoça perguntava a um passageiro se ele gostaria de beber alguma coisa. O passageiro, em resposta, perguntava quais seriam as opções. A aeromoça, por seu turno, respondia que as opções seriam "sim" e "não".

Se a moral dessa propaganda é mostrar a restrição de opções, o que dizer se em um campo tão sério como as eleições políticas não houver a opção "não".

Com efeito, trata-se de escolher pessoas para representar os anseios da nação, para decidir os rumos a serem tomados pelo país, para implantar soluções para os maiores problemas da sociedade.

Nesse contexto, o tema do presente artigo é a análise do voto em branco e do voto nulo e as repercussões que eles geram nas eleições. Busca investigar também se esses votos poderiam ser um instrumento para negar algum candidato ou as próprias eleições.

\section{O VOTO EM BRANCO E O VOTO NULO NAS REGRAS DAS ELEIÇÕES PROPORCIONAIS}

Um breve panorama é importante antes de verificar na prática os efeitos jurídicos desses votos e, dessa forma, poder apurar a que finalidade se prestam.

Por isso, em primeiro lugar, será feita uma investigação em relação às eleições proporcionais. O sistema proporcional, segundo PINTO FERREIRA ${ }^{1}$, destina-se a formar uma representação parlamentar proporcionalmente correspondente à força numérica de cada partido.

O Código Eleitoral, Lei $n^{\circ} 4.737$, de 15 de julho de $1965^{2}$, foi editado durante a vigência do Ato Institucional de 9 de abril de 1964 e se destinava à regulação das eleições diretas, uma vez que, na Constituição então vigente, havia cargos ocupados mediante eleições indiretas.

Nele já se encontra a compulsoriedade do alistamento, salvo aos inválidos, aos maiores de setenta anos e aos ausentes do país, bem como a obrigatoriedade do voto, exceto para os enfermos, os que estivessem fora do domicílio ou os funcionários civis e militares, em serviço que os impossibilitasse de votar.

$\mathrm{O}$ art. 84 prevê que a eleição para os cargos de Deputado Federal, de Deputado Estadual e de Vereador observará o princípio da representação proporcional, isto é, conforme determina o art. 108, "estarão eleitos tantos candidatos registrados por um Partido ou coligação quantos o

\footnotetext{
${ }^{1}$ Código eleitoral comentado. 3.ed. São Paulo: Saraiva, 1991, p. 154.

${ }^{2}$ BRASIL. Lei $\mathrm{n}^{\circ} 4.737$, de 15 de julho de 1965 . Institui o código eleitoral. Planalto.gov.br. Disponível em: <http://www.planalto.gov.br/ccivil_03/leis/14737.htm> Acesso em: 6.ago.2014.
} 
respectivo quociente partidário indicar, na ordem da votação nominal que cada um tenha recebido".

As principais normas relativas ao sistema de representação proporcional estão nos arts. 105 a 113 do Código Eleitoral ${ }^{3}$.

$\mathrm{O}$ art. 106 do Código Eleitoral prevê que o quociente eleitoral é obtido "dividindo-se o número de votos válidos apurados pelo de lugares a preencher em cada circunscrição eleitoral, desprezada a fração se igual ou inferior a meio, equivalente a um, se superior."

Aqui, um primeiro ponto importante acerca do voto em branco: o parágrafo único do art. 106 considerava que os votos em branco seriam válidos para determinação do quociente eleitoral. A Lei n ${ }^{\circ} 9.504$, de 30 de setembro de $1997^{4}$, contudo, revogou o parágrafo único do art. 106.

Juridicamente, o contrário de válido é inválido, ou mais comumente a nulidade. $\mathrm{O}$ termo invalidade, todavia, é mais amplo por albergar tanto a nulidade quanto a anulabilidade ${ }^{5}$.

O voto é a "manifestação individual que é parte de uma decisão coletiva", nas palavras de SÉRGIO SÉRVULO DA CUNHA .

A nulidade priva o ato do efeito jurídico que surgiria se fosse válido o ato ${ }^{7}$. Dessa forma, se o voto válido serve para manifestar a escolha de certo candidato ou partido para ocupar determinado cargo, isso não será alcançado com um voto nulo.

Com as urnas eletrônicas, reduziu-se a margem de possibilidades que os eleitores tinham para anular seu voto. Atualmente, a nulidade fica restrita, em princípio, às hipóteses em que o eleitor digita na urna um número que não corresponde a nenhum candidato ou partido.

Esse voto nulo não se confunde com aquele mencionado no art. 224 do Código Eleitoral $^{8}$, que tem o condão de anular as eleições, quando em certa quantidade ${ }^{9}$.

\footnotetext{
3 “Art. 105 - Fica facultado a 2 (dois) ou mais Partidos coligarem-se para o registro de candidatos comuns a deputado federal, deputado estadual e vereador. $\S 1^{\circ}$ - A deliberação sobre coligação caberá à Convenção Regional de cada Partido, quando se tratar de eleição para a Câmara dos Deputados e Assembleias Legislativas, e à Convenção Municipal, quando se tratar de eleição para a Câmara de Vereadores, e será aprovada mediante a votação favorável da maioria, presentes $2 / 3$ (dois terços) dos convencionais, estabelecendo-se, na mesma oportunidade, o número de candidatos que caberá a cada Partido. $\S 2^{\circ}$ - Cada Partido indicará em Convenção os seus candidatos e o registro será promovido em conjunto pela Coligação. Art. 106. Determina-se o quociente eleitoral dividindo-se o número de votos válidos apurados pelo de lugares a preencher em cada circunscrição eleitoral, desprezada a fração se igual ou inferior a meio, equivalente a um, se superior. Art. 107 - Determina-se para cada Partido ou coligação o quociente partidário, dividindo-se pelo quociente eleitoral o número de votos válidos dados sob a mesma legenda ou coligação de legendas, desprezada a fração. Art. 108 - Estarão eleitos tantos candidatos registrados por um Partido ou coligação quantos o respectivo quociente partidário indicar, na ordem da votação nominal que cada um tenha recebido. Art. 109 - Os lugares não preenchidos com a aplicação dos quocientes partidários serão distribuídos mediante observância das seguintes regras: I - dividir-se-á o número de votos válidos atribuídos a cada Partido ou coligação de Partidos pelo número de lugares por ele obtido, mais um, cabendo ao Partido ou coligação que apresentar a maior média um dos lugares a preencher; II - repetir-se-á a operação para a distribuição de cada um dos lugares. $\S 1^{\circ}$ - O preenchimento dos lugares com que cada Partido ou coligação for contemplado far-se-á segundo a ordem de votação recebida pelos seus candidatos. $\S 2^{\circ}$ - Só poderão concorrer à distribuição dos lugares os Partidos e coligações que tiverem obtido quociente eleitoral. Art. 110. Em caso de empate, haver-se-á por eleito o candidato mais idoso. Art. 111 - Se nenhum Partido ou coligação alcançar o quociente eleitoral, considerar-se-ão eleitos, até serem preenchidos todos os lugares, os candidatos mais votados. Art.112. Considerar-se-ão suplentes da representação partidária: I - os mais votados sob a mesma legenda e não eleitos efetivos das listas dos respectivos partidos; II - em caso de empate na votação, na ordem decrescente da idade. Art. 113. Na ocorrência de vaga, não havendo suplente para preenchê-la, far-se-á eleição, salvo se faltarem menos de nove meses para findar o período de mandato.”

${ }^{4}$ BRASIL. Lei ${ }^{\circ} 9.504$, de 30 de setembro de 1997. Estabelece normas para as eleições. Planalto.gov.br. Disponível em: <http://www.planalto.gov.br/ccivil_03/leis/19504.htm> Acesso em: 8.ago.2014

${ }^{5}$ MELLO, Marcos Bernardes de. Teoria do fato jurídico: plano da validade. 6.ed. São Paulo: Saraiva, 2004, p.4-6.

${ }^{6}$ Dicionário compacto do direito. 2.ed. São Paulo: Saraiva, 2003, p. 258.

${ }^{7}$ PINTO FERREIRA, Código eleitoral comentado. 3.ed. São Paulo: Saraiva, 1991, p. 235.

8 "Art. 224. Se a nulidade atingir a mais de metade dos votos do País nas eleições presidenciais, do Estado nas eleições federais e estaduais ou do Município nas eleições municipais, julgar-se-ão prejudicadas as demais votações e o Tribunal marcará dia para nova eleição dentro do prazo de 20 (vinte) a 40 (quarenta) dias."
} 
Continuando a análise acerca da revogação do parágrafo único do art. 106 do Código Eleitoral, parece que a intenção do legislador foi equiparar o voto em branco ao nulo, uma vez que a Lei $\mathrm{n}^{\circ}$ 9.504, de 1997, previu em seu art. $5^{\mathbf{0}}$ que "nas eleições proporcionais, contam-se como votos válidos apenas os votos dados aos candidatos regularmente inscritos e às legendas partidárias." Assim, de fato, votos brancos e nulos, nas eleições proporcionais, não serão considerados válidos.

Segundo consta da discussão havida na Câmara dos Deputados acerca das emendas efetuadas pelo Senado no Projeto de Lei no 2.695-E, de 1997, que deu origem à Lei no 9.504, de 1997:

A inclusão dos votos em branco no cálculo do quociente eleitoral é prevista em nosso Código Eleitoral e não tem similar no direito de povos democráticos, como o alemão, o português, o espanhol, o francês e, na América Latina, o mexicano, o argentino, o peruano e o uruguaio, todos adeptos do sistema de representação proporcional para as Casas Legislativas.

Somos pela manutenção do art. $5^{\circ}$ do texto aprovado pela Câmara, o qual determina a contagem como válidos, nas eleições proporcionais, apenas dos votos dados a candidatos regularmente inscritos e às legendas partidárias. Não nos parece legítimo a lei aproveitar os votos em branco, que não expressam opção eleitoral do votante para a atribuição de cadeiras parlamentares aos $\operatorname{partidos}^{10}$.

Da obra de PINTO FERREIRA ${ }^{11}$, por outro lado, extrai-se o seguinte:

A questão dos votos em branco não foi novidade da Lei n. 48, parágrafo único de seu art. 91. Já havia sido examinada essa questão por ocasião das eleições de 14 de outubro de 1934, na vigência do Decreto n. 21.076, que dispunha em seu art. 58, n. 6: "Determina-se o quociente eleitoral dividindo-se o número de eleitores que concorreram à eleição pelo número de lugares a preencher no círculo eleitoral, desprezada a fração'. Vê-se que ali não se falava em votos válidos, mas de eleitores que compareceram à eleição. O Tribunal Superior, em acórdão de que foi relator o Sr. Ministro Eduardo Espínola, interpretou que os votos nulos não se poderiam considerar como de eleitores que compareceram à eleição, porque votos nulos não existem, é como se nunca tivessem sido dados. Ora, os votos em branco não são nulos, os eleitores que assim votaram não podem deixar de ser considerados como tendo comparecido à eleição. A citada Lei n. 48 e a nova Lei, portanto, tornaram expresso o que a doutrina já firmara pela voz autorizada do mais alto tribunal eleitoral."

Também de certa forma contrário ao fato de os votos brancos deixarem de ser válidos, JOEL J. CÂNDIDO ${ }^{12}$ assim se pronunciou:

\footnotetext{
${ }^{9}$ Sobre estes últimos, assim já se manifestou o TSE: “Ac.-TSE, de 29.6.2006, no MS no 3.438 e de 5.12.2006, no REspe $n^{\circ}$ 25.585: 'Para fins de aplicação do art. 224 do Código Eleitoral, não se somam aos votos anulados em decorrência da prática de captação ilícita de sufrágio os votos nulos por manifestação apolítica de eleitores'. Res.TSE $n^{\circ}$ 22.992/2008: 'Os votos dados a candidatos cujos registros encontravam-se sub judice, tendo sido confirmados como nulos, não se somam, para fins de novas eleições (art. 224, CE), aos votos nulos decorrentes de manifestação apolítica do eleitor'. (Brasil. Tribunal Superior Eleitoral. Código eleitoral anotado e legislação complementar. 11. ed. Brasília: Tribunal Superior Eleitoral, Secretaria de Gestão da Informação, 2014, p. 98). Em razão disso, como se verá, o voto nulo, em princípio, não se prestaria para anular as eleições, salvo se não houvesse nenhum voto válido, hipótese em que novas eleições seriam a única alternativa razoável para solucionar o problema daí decorrente.

${ }^{10}$ DIÁRIO DA CÂMARA DOS DEPUTADOS, Ano LII, no 170, Brasília, DF, 24.set.1997, p. 29.391.

${ }^{11}$ Código eleitoral comentado. 3.ed. São Paulo: Saraiva, 1991, p. 176. Cf. ainda na mesma obra as p. 247-248.

${ }^{12}$ Direito eleitoral brasileiro. 13. ed. Bauru, SP: Edipro, 2008, p.386-387.
}

Revista de Direito Brasileira | São Paulo, SP | v. 18 | n. 7 | p. 331 - 351 | Set./Dez. 2017 
Muito polêmico na elaboração da lei, este art. $5^{\circ}$ revogou o parágrafo único do art. 106 do Código Eleitoral, e, a partir de agora, em qualquer eleição proporcional no País, o "voto em branco" não interfere mais no quociente eleitoral e, por conseguinte, indiretamente, no quociente partidário.

Acabou-se, assim, uma tradição em nosso ordenamento eleitoral que vinha desde 1935.

Não cremos no acerto da medida.

$\mathrm{O}$ voto em branco é voto válido porque não ofende à ordem jurídica, como acontece com o voto nulo, mesmo o nulo acidental. Devia, por isso, ser valorado. Trata-se de voto de eleitor que, por qualquer razão, não foi conquistado por qualquer partido ou candidato. Faltou habilidade na conquista desse voto - ou porque a nominata dos candidatos não agradou, ou porque os programas e plataformas não convenceram, etc. - e, assim, o Estado, por isso, não tem culpa. A culpa é de todos os partidos e candidatos. Devem arcar com esse ônus, igualmente, enfrentando um quociente eleitoral mais alto, o que ocorre com a inclusão dos votos em branco no cálculo desse quociente.

Por outro lado, o principal argumento para justificar a novidade - segundo o qual a inclusão prejudicava os "pequenos partidos" - é argumento equivocado. O cômputo do voto em branco no cálculo do quociente eleitoral podia prejudicar os partidos "ruins de voto", conceito que não se confunde com "pequenos partidos". Se o partido fosse "bom de voto" não se preocuparia com o quociente eleitoral mais alto, pois teria sufrágios suficientes para enfrenta-lo, fazendo, mesmo assim, um bom número de cadeiras. Com a novidade, houve um auxílio aos medíocres e um estímulo para que continuem incompetentes, pois sem um esforço político maior, podem obter um resultado mais satisfatório. Partido que tinha bastante voto não precisava da novidade; partido de poucos sufrágios foi por ela beneficiado. As "siglas de aluguem" devem ter gostado da mudança.

Concordemos ou não com a nova regra, verdade é que, com ela, o quociente eleitoral será, sempre, menor; o quociente partidário será sempre maior e, assim, maior será a possibilidade de o partido obter mais cadeiras.

Essa é a consequência prática da mudança.

O STF já havia entendido ser constitucional o dispositivo revogado ${ }^{13}$ :

Constitucional. Eleitoral. Votos em branco. Eleições proporcionais. Quociente eleitoral: determinação. Código Eleitoral, art. 106, parágrafo único. Compatibilidade com a Constituição. A norma inscrita no parágrafo único do art. 106 do Código Eleitoral, a dizer que 'contam-se como válidos os votos em branco para determinação do quociente eleitoral', não é incompatível com a Constituição vigente.

O fato de o voto em branco deixar de ser válido repercute em outras normas, como a do art. 107, que, segundo redação dada pela Lei no 7.454, de 30 de dezembro de 1985, prevê: “Art. 107 - Determina-se para cada Partido ou coligação o quociente partidário, dividindo-se pelo quociente eleitoral o número de votos válidos dados sob a mesma legenda ou coligação de legendas, desprezada a fração."

Entre as demais normas pertinentes, cabe mencionar o art. 109, segundo o qual os lugares não preenchidos com a aplicação dos quocientes partidários serão distribuídos mediante a observação das regras que estabelece. Por essas regras, divide-se o número de votos válidos atribuídos a cada partido pelo número de lugares por ele obtido, mais $\mathrm{um}^{14}$, cabendo ao partido

\footnotetext{
${ }^{13}$ RE 140.386, Rel. Min. Carlos Velloso, julgamento em 19-5-1993, Plenário, DJ de 20-4-2001.

${ }^{14}$ Segundo FRANCISCO DIRCEU BARROS (2010, p.70), soma-se 1 com o quociente partidário e depois se efetua a divisão.
} 
que apresentar a maior média um dos lugares a preencher. Daí, repete-se a operação para a distribuição dos demais lugares.

O preenchimento de cada lugar atribuído segundo essa média é feita, segundo o $\$ 1^{\circ}$ do art. 109, observando a ordem de votação nominal dos candidatos.

Havendo empate, o art. 110 do Código Eleitoral prevê que será eleito o candidato mais idoso. Porém, o TSE estabeleceu que essa regra somente é utilizada após outros dois critérios, sendo o primeiro a maior quantidade de votos ao partido ou coligação e o segundo a maior quantidade de votos nominais. ${ }^{15}$

Contudo, cabe lembrar que, de acordo com o $\$ 2^{\circ}$ do art. 109, somente "poderão concorrer à distribuição dos lugares os partidos que tiverem obtido quociente eleitoral."

Essa última regra deve ser interpretada juntamente com o art. 111, que soluciona os casos em que nenhum partido alcançar o quociente eleitoral. Nessa situação, os lugares serão preenchidos pelos candidatos mais votados.

Uma vez preenchidos os lugares, os demais candidatos mais votados sob a mesma legenda e não eleitos efetivos das listas dos respectivos partidos serão considerados suplentes, sendo que, em caso de empate, será observada a ordem decrescente de idade. São essas as regras do art. 112 do Código Eleitoral.

Por fim, se houver vaga e não houver suplente para seu preenchimento, será necessário realizar outra eleição, exceto se faltarem menos de nove meses para findar o período de mandato, conforme determina o art. 113 do Código Eleitoral.

É curioso notar que, na prática, essas normas vêm sendo interpretadas de modo a permitir que candidatos sem votos sejam eleitos, desde que puxados por outros candidatos de seu partido ou coligação que tenham recebido votos. Da mesma forma os suplentes ${ }^{16}$.

Em razão disso, o Deputado CARLOS BEZERRA apresentou o Projeto de Lei ${ }^{\circ}$ 4.169, de 2008, para acrescentar o art. 113-A no Código Eleitoral, com a seguinte redação: “Art. 113-A Nas eleições proporcionais, não poderá preencher vaga suplente que não tenha recebido nenhum voto.” Eis a justificativa do projeto:

A legislação eleitoral hoje vigente vem permitindo a ocorrência de situações frontalmente contrárias ao sistema representativo e atentatórias à cláusula pétrea do voto direto, secreto, universal e periódico consagrada pela Constituição Federal.

Veja-se, por exemplo, o que ocorreu recentemente, no Município piauiense de Queimada Nova. Um vereador, que não obteve nenhum voto nas eleições, foi empossado na Câmara Municipal. Isto porque três vereadores e seus suplentes foram cassados por infidelidade partidária, não tendo sobrado nenhum suplente da coligação.

Não podemos admitir que essas situações continuem a macular o sistema eleitoral, em detrimento do direito de voto e, em última instância, do exercício da função legislativa na Câmara dos Deputados, nas Assembleias Legislativas e nas Câmaras Municipais.

\footnotetext{
15 “Res.-TSE n $16.844 / 1990$ e Ac.-TSE n os 11.778/1994 e 2.895/2001: no caso de empate na média entre dois ou mais partidos ou coligações, considerar-se-á o partido ou coligação com maior votação, não se aplicando o art. 110 do CE/65. Ac.-TSE n 2.845/2001: no caso de empate na média e no número de votos, deve ser usado como terceiro critério de desempate o número de votos nominais" (BRASIL. Tribunal Superior Eleitoral. Código eleitoral anotado e legislação complementar. 11. ed. Brasília: Tribunal Superior Eleitoral, Secretaria de Gestão da Informação, 2014, p.68).

16 'PUXADORES' de votos: candidatos que conseguem eleger a legenda. Acrítica. Manaus 4.mai.2014. Disponível em: <http://acritica.uol.com.br/noticias/Puxadores-candidatos-conseguem-eleger-legenda_0_1132086784.html> Acesso em: 5.jun.2014; ROLLO, Alberto. Candidato do Prona é eleito mesmo sem nenhum voto. Consultor Jurídico. 7.out.2002. Disponível em: <http://www.conjur.com.br/2002-out-07/candidato_prona_eleito_ mesmo_nenhum_voto> Acesso em: 5.6.2014.
} 
Deve ser notado, todavia, que, apesar de impedir um candidato suplente sem votos de ocupar vaga, nada disse sobre um candidato ser eleito sem votos, fato que também ocorre, como visto acima.

O TSE já se pronunciou, de certa forma, sobre o assunto. No Agravo de Instrumento $\mathrm{n}^{\circ}$ 4096, consta que nas eleições de 15 de novembro de 1972 para 15 cadeiras de vereador do Município de Poços de Caldas/MG, a Arena registrou 11 candidatos e o MDB 6. Foram eleitos todos os candidatos da Arena e apenas 2 do MDB, preenchendo, assim apenas 13 das 15 vagas. Pelo critério das sobras, o MDB não conseguiu obter essas últimas 2 vagas, alegando, então, ofensa ao art. 111 do Código Eleitoral. Julgado o caso, o TSE entendeu ${ }^{17}$ :

1) $\mathrm{O}$ art. 111 do código eleitoral só tem aplicação a hipótese de nenhum partido haver alcançado o quociente eleitoral.

2) o art. 119 do mesmo código leva a conclusão de que, existindo vagas, seu preenchimento devera ser feito por nova eleição.

3) o art. 113 do citado código também não poderia ocorrer ao agravante, pois a convocação do suplente pressupõe vaga superveniente a eleição.

4) agravo desprovido. ${ }^{18}$

PINTO FERREIRA ${ }^{19}$, a propósito do suplente, lembra que a finalidade é permitir a manutenção da proporcionalidade da representação partidária. Dessa forma, de determinado partido recebeu mais votos e um de seus candidatos eleitos falece, é necessário que seu lugar seja ocupado por outro candidato do mesmo partido para manter a proporção alcançada na eleição.

\subsection{Análise prática}

Com essas premissas colocadas, exemplos práticos são necessários para entender sua aplicação. Primeiro, será analisada a repercussão dos votos em branco tomando-os como são na legislação atual, isto é, sem contá-los. Depois, serão formulados exemplos em que, por hipótese, os votos em branco sejam considerados válidos.

\subsubsection{Primeiro exemplo}

Pode-se tomar como primeiro exemplo um caso real, consistente nas eleições para a Câmara de Vereadores do Município de Borá/SP em 2012, uma vez que seu pequeno número de eleitores facilita sua utilização.

Eis os dados da Justiça Eleitoral sobre esse Município (http://www.tse.jus.br/eleicoes/estatisticas/estatisticas-eleicoes-2012):

Quadro de comparecimento:

\begin{tabular}{|c|r|r|r|r|}
\hline \multicolumn{1}{|c|}{ Abrangência } & Qt Aptos & Qt Aptos Totalizados & \multicolumn{1}{c|}{ Comparecimento } & \multicolumn{2}{c|}{ Abstenção } \\
\hline BORÁ & 1.071 & 1.071 & 994 & 77 \\
\hline
\end{tabular}

17 AGRAVO DE INSTRUMENTO no 4096, Acórdão no 5459 de 11/09/1973, Relator Min. MÁRCIO RIBEIRO, Publicação: BEL - Boletim Eleitoral, Volume 268, Tomo 1, Página 1303.

${ }^{18}$ Analisando esse julgado, nota-se que a referência ao art. 119 está claramente equivocada, pois seus termos não têm nenhuma relação com o caso: “Art. 119. A cada Seção Eleitoral corresponde uma Mesa Receptora de votos."

${ }^{19}$ Código eleitoral comentado. 3.ed. São Paulo: Saraiva, 1991, p.135-137. 
Quadro de votação:

\begin{tabular}{|l|r|r|r|r|r|r|}
\hline \multicolumn{1}{|c|}{ Abrangência } & Qt Comparecimento & $\begin{array}{c}\text { Qt Votos } \\
\text { Nominais }\end{array}$ & $\begin{array}{l}\text { Qt Votos } \\
\text { Legenda }\end{array}$ & $\begin{array}{c}\text { Qt Votos } \\
\text { em Branco }\end{array}$ & $\begin{array}{c}\text { Qt Votos } \\
\text { Nulos }\end{array}$ & $\begin{array}{c}\text { Qt Votos } \\
\text { Válidos }\end{array}$ \\
\hline BORÁ & 994 & 874 & 48 & 16 & 56 & 922 \\
\hline
\end{tabular}

Dos eleitores que compareceram, 874 votaram em algum candidato específico e 48 na legenda. Como se vê nessa última tabela, somente votos nominais e em legenda, segundo a legislação vigente, foram considerados como válidos, pois $874+48=922$.

A quantidade de cargos de vereador no Município é de 9, isto é, o mínimo, segundo o art. 29, IV, a da Constituição, para Municípios com população até 15.000 habitantes.

Assim, considerando que o quociente eleitoral se obtém pela divisão do número de votos válidos pelo número de cargos a ocupar, no caso ele é igual a 922 / $9=102,44$, valor este que, desprezando-se a fração de 0,44, segundo o art. 106 do Código Eleitoral -por ser inferior a 0,5resulta 102.

Já o quociente partidário é obtido pela divisão do número de votos válidos do partido pelo quociente eleitoral, desprezando-se a fração. Assim, tem-se para o PSB 236 votos válidos divididos pelo quociente eleitoral de 102, que é igual a 2,31, isto é, 2. Para a coligação PT/PSD, $416 / 102=4,078$, isto é, 4. Por fim, para a coligação PTB/PMDB/DEM/PV/PSDB, 270/102= 2,647, isto é, 2.

Eis a tabela com os quocientes eleitoral e partidário:

\begin{tabular}{|c|c|c|c|c|c|c|c|}
\hline UF & Município & $\begin{array}{l}\text { Qt Votos } \\
\text { Válidos }\end{array}$ & $\begin{array}{c}\text { Qt Vagas } \\
\text { QE }\end{array}$ & QE & Legenda & $\begin{array}{c}\text { Qt Votos } \\
\text { Válidos QP }\end{array}$ & $\begin{array}{c}\text { Qt Vagas } \\
\text { QP }\end{array}$ \\
\hline SP & BORÁ & 922 & 9 & 102 & PSB & 236 & 2 \\
\hline SP & BORÁ & 922 & 9 & 102 & PT / PSD & 416 & 4 \\
\hline SP & BORÁ & 922 & 9 & 102 & PTB / PMDB / DEM / PV / PSDB & 270 & 2 \\
\hline
\end{tabular}

O preenchimento dos lugares ocorre segundo as normas já mencionadas dos arts. 108 e seguintes do Código Eleitoral.

Segundo essas regras, em primeiro lugar, sabe-se que o PSB tem direito a 2 vagas, a coligação PT/PSD tem direito a 4 e a coligação PTB/PMDB/DEM/PV/PSDB tem direito a 2. Essas vagas são ocupadas segundo a ordem de classificação dos candidatos mais votados.

Em 2012, o candidato mais votado em Borá foi Paulo Sérgio dos Santos, com 86 votos, do PSB. Ele ocupou, então 1 das 2 vagas do PSB, sendo eleito pelo quociente partidário.

O segundo mais votado, eleito pelo quociente partidário foi Paulo Roberto Gonçalves Gusmão, do PT, com 82 votos, ocupando, então 1 das 4 vagas da coligação PT/PSD.

$\mathrm{O}$ terceiro mais votado foi Wilson Canato, do PT, eleito pelo quociente partidário com 53, ocupando a segunda das 4 vagas da coligação PT/PSD.

O quarto foi Márcio Leovezete, do PSD, eleito pelo quociente partidário com 52 votos, ocupando a terceira vaga das 4 a que tinha direito a coligação PT/PSD.

$\mathrm{O}$ quinto foi Sebastião Carlos Pietro, do PMDB, eleito segundo o quociente partidário com 48 votos, ocupando 1 das 2 vagas da coligação PTB/PMDB/DEM/PV/PSDB.

$\mathrm{O}$ sexto foi Edson Alves dos Santos, do PT, eleito pelo quociente partidário com 40 votos para ocupar a última das 4 vagas a que a coligação PT/PSD teria direito.

O sétimo foi Robson Donley, do PSB, eleito pelo quociente partidário com 37 votos e, portanto, ocupando a última das 2 vagas de direito de seu partido.

O oitavo mais votado foi Celso Soares, do PT, com 33 votos. Como a coligação de seu partido já havia preenchido as 4 vagas de direito pelo quociente partidário, ele ficou como suplente, segundo o art. 112, I, do Código Eleitoral.

O mesmo ocorreu com o nono candidato mais votado, Pedro Correia da Costa, também do PT, com 31 votos. 
José Aprigio dos Santos, do PSDB, teve 31 votos e foi eleito pelo quociente partidário, ocupando a última das 2 vagas da coligação $P T B / P M D B / D E M / P V / P S D B$.

Ocorre que, embora preenchidos os cargos segundo o quociente partidário, o Município ainda possui 1 vaga de vereador em aberto, já que há 9 cargos e só foram preenchidos 8 cargos. Assim, aplicam-se as regras do art. 109 para preencher essa vaga, ou seja, divide-se o número de votos válidos do partido ou coligação pelo número de lugares obtidos, mais um, de modo que o partido ou coligação com maior média preenche a vaga. Se houvesse mais vagas, essa operação teria que ser repetida até completar os cargos, mas não é o caso aqui.

Seguindo essa regra, o PSB tem 236 votos válidos. Deve-se dividir esse número pelo número de lugares obtidos (2) mais 1 , ou seja, divide-se por 3 , resultando a média $78,666666^{20}$. A coligação PT/PSD possui 416 votos válidos, que, divididos por $5(=4+1)$, gera a média 83,2. Por fim, a coligação $P T B$ / $P M D B$ / DEM / PV / PSDB recebeu 270 votos válidos, que divididos por 3 $(2+1)$ resulta na média 90. A maior média, assim, é da coligação $P T B / P M D B / D E M / P V /$ $P S D B$, que passa, então, a ter 3 lugares ocupados.

Daí, seguindo o $§ 1^{\circ}$ do art. 109 do Código Eleitoral, busca-se o próximo candidato mais votado do partido ou coligação, que, no caso, é Iracema Benedita Ribeiro Vinhando, do DEM, com 31 votos, eleita, assim, pela média e ocupando o último dos 9 cargos de vereador do município.

Os demais candidatos ficaram como suplentes ou não foram eleitos, seguindo as citadas regras.

Eis o resultado da eleição:

\begin{tabular}{|c|c|c|c|c|c|c|c|c|}
\hline UF & Município & Cargo & $\mathrm{Nr}$ & Candidato & Partido & Situação & $\begin{array}{l}\text { Qt Votos } \\
\text { Válidos }\end{array}$ & \% Válidos \\
\hline SP & BORÁ & Vereador & 40.650 & PAULO SERGIO DOS SANTOS & PSB & Eleito por QP & 86 & 9,328 \\
\hline SP & BORÁ & Vereador & 13.111 & PAULO ROBERTO GONÇALVES GUSMÃO & PT & Eleito por QP & 82 & 8,894 \\
\hline SP & BORÁ & Vereador & 13.567 & WILSON CANATO & PT & Eleito por QP & 53 & 5,748 \\
\hline SP & BORÁ & Vereador & 55.650 & MÁRCIO LEOVEZETE & PSD & Eleito por QP & 52 & 5,640 \\
\hline SP & BORÁ & Vereador & 15.100 & SEBASTIÃO CARLOS PIETRO & PMDB & Eleito por QP & 48 & 5,206 \\
\hline SP & BORÁ & Vereador & 13.555 & EDSON ALVES DOS SANTOS & PT & Eleito por QP & 40 & 4,338 \\
\hline SP & BORÁ & Vereador & 40.123 & ROBSON DONLEY & PSB & Eleito por QP & 37 & 4,013 \\
\hline SP & BORÁ & Vereador & 13.620 & CELSO SOARES & PT & Suplente & 33 & 3,579 \\
\hline SP & BORÁ & Vereador & 13.640 & PEDRO CORREIA DA COSTA & PT & Suplente & 31 & 3,362 \\
\hline SP & BORÁ & Vereador & 25.333 & IRACEMA BENEDITA RIBEIRO VINHANDO & DEM & Eleito por média & 31 & 3,362 \\
\hline SP & BORÁ & Vereador & 45.555 & JOSE APRIGIO DOS SANTOS & PSDB & Eleito por QP & 31 & 3,362 \\
\hline SP & BORÁ & Vereador & 40.222 & DOMILSON DOMINGOS DOS SANTOS & PSB & Suplente & 30 & 3,254 \\
\hline SP & BORÁ & Vereador & 40.333 & VALDINEI TOLEDO & PSB & Suplente & 27 & 2,928 \\
\hline SP & BORÁ & Vereador & 55.630 & DEVANIR PEREIRA DA ROCHA & PSD & Suplente & 26 & 2,820 \\
\hline SP & BORÁ & Vereador & 45.330 & ANGELO APARECIDO DA SILVA & PSDB & Suplente & 21 & 2,278 \\
\hline SP & BORÁ & Vereador & 25.000 & WILSON AZEVEDO & DEM & Suplente & 21 & 2,278 \\
\hline SP & BORÁ & Vereador & 25.250 & EDUARDO CALDAS & DEM & Suplente & 20 & 2,169 \\
\hline SP & BORÁ & Vereador & 13.100 & ADEMIR FERREIRA & PT & Suplente & 19 & 2,061 \\
\hline SP & BORÁ & Vereador & 40.444 & SILVANA DE BEN & PSB & Suplente & 18 & 1,952 \\
\hline SP & BORÁ & Vereador & 43.000 & CRISTIANE CAZARIN & PV & Suplente & 17 & 1,844 \\
\hline SP & BORÁ & Vereador & 40.014 & ADELINA MENDES DOS SANTOS & PSB & Suplente & 16 & 1,735 \\
\hline SP & BORÁ & Vereador & 45.650 & JOSE APARECIDO ALBERTINI & PSDB & Suplente & 15 & 1,627 \\
\hline SP & BORÁ & Vereador & 13.333 & ERNESTINA GOMES SILVA & PT & Suplente & 14 & 1,518 \\
\hline SP & BORÁ & Vereador & 40.240 & CARLOS DA SILVA & PSB & Suplente & 12 & 1,302 \\
\hline SP & BORÁ & Vereador & 55.678 & ARTUR EDSON BREGOLATO & PSD & Suplente & 12 & 1,302 \\
\hline SP & BORÁ & Vereador & 45.300 & ALEX PEREIRA DOS SANTOS & PSDB & Suplente & 11 & 1,193 \\
\hline SP & BORÁ & Vereador & 13.145 & EDERALDO EVARISTO DE SOUZA & PT & Suplente & 10 & 1,085 \\
\hline
\end{tabular}

${ }^{20}$ A Resolução do TSE no $16.844 / 90$ prevê que "para o cálculo da média deverá ser considerada a fração, até a $14^{\mathrm{a}}$ casa decimal.” (BRASIL. Tribunal Superior Eleitoral. Código eleitoral anotado e legislação complementar. 11. ed. Brasília: Tribunal Superior Eleitoral, Secretaria de Gestão da Informação, 2014, p.68) Mas no caso não é necessário usar tantas casas. 


\begin{tabular}{l|l|l|l|l|l|l|r|r|} 
SP & BORÁ & Vereador & 43.043 & BRUNO ALVES DA SILVA & PV & Suplente \\
\hline SP & BORÁ & Vereador & 15.021 & RONALDO ANTUNES DE BEM & PMDB & Suplente & 0,651 \\
\hline SP & BORÁ & Vereador & 40.013 & NADIA ANGELICA FAVATO FRANCO & PSB & Suplente \\
\hline SP & BORÁ & Vereador & 13.023 & MARIA LUCIANA DA SILVA MENDES & PT & Suplente & 0,542 \\
\hline SP & BORÁ & Vereador & 14.000 & MARCIA LUCIANE DA SILVA & PTB & Suplente & 0,434 \\
\hline SP & BORÁ & Vereador & 55.055 & ELIANA APARECIDA MAYOLLI & PSD & Suplente & 0,325 \\
\hline SP & BORÁ & Vereador & 45.045 & ADVALDO CELESTINO TEIXEIRA & & PSDB & Não eleito & 0,108 \\
\hline & & & & & & & 0,000 \\
\hline
\end{tabular}

\subsubsection{Segundo exemplo}

Aqui será tomada a hipótese anterior, isto é, será mantido o número de votos nulos, mas os votos nominais de todos os candidatos após José Aprígio dos Santos, do PSDB, serão considerados votos em branco e esses candidatos ficarão com votos zerados. Os votos em branco, como visto, pela legislação atual, não são contados no sistema proporcional.

Assim, somando os votos dos candidatos com menos votos do que José Aprígio dos Santos, obtêm-se 350 votos, que, somados com os 16 votos em branco originais, resulta 366 votos em branco.

O Quadro de votação fica assim:

\begin{tabular}{|l|r|r|r|r|r|r|}
\hline \multicolumn{1}{|c|}{ Abrangência } & Qt Comparecimento & \multicolumn{1}{|c|}{$\begin{array}{c}\text { Qt Votos } \\
\text { Nominais }\end{array}$} & $\begin{array}{l}\text { Qt Votos } \\
\text { Legenda }\end{array}$ & $\begin{array}{c}\text { Qt Votos } \\
\text { em Branco }\end{array}$ & $\begin{array}{c}\text { Qt Votos } \\
\text { Nulos }\end{array}$ & $\begin{array}{c}\text { Qt Votos } \\
\text { Válidos }\end{array}$ \\
\hline BORÁ & 994 & 524 & 48 & 366 & 56 \\
\hline
\end{tabular}

Uma primeira alteração, então, ocorre aqui, com os votos válidos caindo para 572.

O PSB fica com 123 votos nominais válidos e mantém 6 votos em sua legenda, totalizando 129 votos. A coligação PT/PSD fica com 291 votos nominais válidos e mantém 26 votos em sua legenda, totalizando 317 votos. A coligação PTB/PMDB/DEM/PV/PSDB fica com 110 votos nominais válidos e mantém 16 votos em sua legenda, totalizando 126 votos.

Havendo 9 lugares a ocupar na Câmara de Vereadores do Município de Borá/SP e 572 votos válidos, o quociente eleitoral é 64 (572 / $9=63,55=64)$.

Quanto ao quociente partidário, tem-se:

PSB: 129 / 64 = 2,01, que, sem a fração, fica 2.

PT / PSD: 317 / $64=4,95$ que, sem a fração, fica 4.

PTB / PMDB / DEM / PV / PSDB: 126 / 64 = 1,96, que, sem a fração, fica 1.

Quadro de quocientes eleitoral e partidário:

\begin{tabular}{c|l|r|r|r|l|r|r|}
\hline UF & \multicolumn{1}{|c|}{ Município } & $\begin{array}{c}\text { Qt Votos } \\
\text { Válidos }\end{array}$ & $\begin{array}{c}\text { Qt Vagas } \\
\text { QE }\end{array}$ & \multicolumn{1}{c|}{ QE } & & $\begin{array}{c}\text { Qt Votos } \\
\text { Válidos QP }\end{array}$ & $\begin{array}{c}\text { Qt Vagas } \\
\text { QP }\end{array}$ \\
\hline SP & BORÁ & 572 & 9 & 64 & PSB & 129 & 2 \\
\hline SP & BORÁ & 572 & 9 & 64 & PT / PSD & 317 & 4 \\
\hline SP & BORÁ & 572 & 9 & 64 & PTB / PMDB / DEM / PV / PSDB & 126 & 1 \\
\hline
\end{tabular}

Usando as regras de distribuição, o candidato mais votado em Borá foi Paulo Sérgio dos Santos, com 86 votos, do PSB. Ele ocupou, então 1 das 2 vagas do PSB, sendo eleito pelo quociente partidário.

O segundo mais votado, eleito pelo quociente partidário, foi Paulo Roberto Gonçalves Gusmão, do PT, com 82 votos, ocupando, então 1 das 4 vagas da coligação PT/PSD.

O terceiro mais votado foi Wilson Canato, do PT, eleito pelo quociente partidário com 53, ocupando a segunda das 4 vagas da coligação PT/PSD.

O quarto foi Márcio Leovezete, do PSD, eleito pelo quociente partidário com 52 votos, ocupando a terceira vaga das 4 a que tinha direito a coligação $\underline{\mathrm{PT} / \mathrm{PSD} \text {. }}$

O quinto foi Sebastião Carlos Pietro, do PMDB, eleito segundo o quociente partidário com 48 votos, ocupando a única vaga da coligação $P T B / P M D B / D E M / P V / P S D B$. 
O sexto foi Edson Alves dos Santos, do PT, eleito pelo quociente partidário com 40 votos para ocupar a última das 4 vagas a que a coligação PT/PSD teria direito.

O sétimo foi Robson Donley, do PSB, eleito pelo quociente partidário com 37 votos e, portanto, ocupando a última das 2 vagas de direito de seu partido.

Assim, foram preenchidas todas as vagas distribuídas pelo quociente partidário, num total de 7. Restam então 2 das 9 vagas do Município, que devem ser preenchidas segundo o critério da média.

Aplicam-se então as regras do art. 109 para preencher essas vagas, ou seja, divide-se o número de votos válidos do partido ou coligação pelo número de lugares obtidos, mais um, de modo que o partido ou coligação com maior média preenche a vaga, repetindo-se o processo até o esgotamento de todas.

Seguindo essa regra, o PSB tem 129 votos válidos, que, divididos por 3 (2 lugares obtido, mais um) resulta 43. A coligação PT/PSD possui 317 votos válidos, que, divididos por 5, gera 63,4. Por fim, a coligação $P T B$ / $P M D B / D E M / P V / P S D B$ recebeu 126 votos válidos, que divididos por 2 resulta 63 . A maior média, assim, é da coligação PT/PSD.

Daí, seguindo o $§ 1^{\circ}$ do art. 109 do Código Eleitoral, busca-se o próximo candidato mais votado da coligação $\underline{\text { PT/PSD, }}$ que é Celso Soares, do PT, que passa a ser eleito pela média.

Resta uma vaga para ser redistribuída por esse sistema. Com isso, o PSB tem 129 votos válidos, que, divididos por 3 (2 lugares obtido, mais um) resulta 43. A coligação PT/PSD possui 317 votos válidos, que, divididos agora por 6 , gera 52,83. Por fim, a coligação $P T B / P M D B$ / $D E M / P V / P S D B$ recebeu 126 votos válidos, que divididos por 2 resulta 63. A maior média, assim, é da coligação $P T B / P M D B / D E M / P V / P S D B$.

Tendo a agora maior média, a coligação $P T B$ / $P M D B$ / DEM / PV / PSDB fica com a última das vagas remanescentes, ocupando-a com IRACEMA BENEDITA RIBEIRO VINHANDO, do DEM.

Os demais candidatos deste exemplo ficam como suplentes.

Eis o resultado da eleição:

\begin{tabular}{|c|c|c|c|c|c|c|c|c|}
\hline UF & Município & Cargo & $\mathrm{Nr}$ & Candidato & Partido & Situação & $\begin{array}{l}\text { Qt Votos } \\
\text { Válidos }\end{array}$ & \% Válidos \\
\hline SP & BORÁ & Vereador & 40.650 & PAULO SERGIO DOS SANTOS & PSB & Eleito por QP & 86 & 9,328 \\
\hline SP & BORÁ & Vereador & 13.111 & PAULO ROBERTO GONÇALVES GUSMÃO & PT & Eleito por QP & 82 & 8,894 \\
\hline SP & BORÁ & Vereador & 13.567 & WILSON CANATO & PT & Eleito por QP & 53 & 5,748 \\
\hline SP & BORÁ & Vereador & 55.650 & MÁRCIO LEOVEZETE & PSD & Eleito por QP & 52 & 5,640 \\
\hline SP & BORÁ & Vereador & 15.100 & SEBASTIÃO CARLOS PIETRO & PMDB & Eleito por QP & 48 & 5,206 \\
\hline SP & BORÁ & Vereador & 13.555 & EDSON ALVES DOS SANTOS & PT & Eleito por QP & 40 & 4,338 \\
\hline SP & BORÁ & Vereador & 40.123 & ROBSON DONLEY & PSB & Eleito por QP & 37 & 4,013 \\
\hline SP & BORÁ & Vereador & 13.620 & CELSO SOARES & PT & Eleito por média & 33 & 3,579 \\
\hline SP & BORÁ & Vereador & 13.640 & PEDRO CORREIA DA COSTA & PT & Suplente & 31 & 3,362 \\
\hline SP & BORÁ & Vereador & 25.333 & IRACEMA BENEDITA RIBEIRO VINHANDO & DEM & Eleito por média & 31 & 3,362 \\
\hline SP & BORÁ & Vereador & 45.555 & JOSE APRIGIO DOS SANTOS & PSDB & Suplente & 31 & 3,362 \\
\hline
\end{tabular}
diferenças.

Essa tabela, comparada com a primeira apresentada, também traz algumas importantes

Celso Soares, que era suplente na tabela original, agora foi eleito pela média.

José Aprígio dos Santos, que foi eleito pelo quociente partidário na tabela original, agora está como suplente.

\subsubsection{Terceiro exemplo}

Aqui, será formulada uma hipótese com base no primeiro exemplo, aumentando ao máximo os votos em branco. Para começar o exemplo, então, serão considerados em branco todos os votos válidos do primeiro exemplo. E esses votos não serão considerados como válidos 
No presente exemplo, é mantido, então, o quadro de comparecimento:

\begin{tabular}{|l|r|r|r|r|}
\hline \multicolumn{1}{|c|}{ Abrangência } & Qt Aptos & Qt Aptos Totalizados & Comparecimento & \multicolumn{1}{|c|}{ Abstenção } \\
\hline BORÁ & 1.071 & 1.071 & 994 & 77 \\
\hline
\end{tabular}

Quadro de votação:

\begin{tabular}{|c|c|c|c|c|c|c|}
\hline Abrangência & Qt Comparecimento & $\begin{array}{l}\text { Qt Votos } \\
\text { Nominais }\end{array}$ & $\begin{array}{l}\text { Qt Votos } \\
\text { Legenda }\end{array}$ & $\begin{array}{l}\text { Qt Votos } \\
\text { em Branco }\end{array}$ & $\begin{array}{l}\text { Qt Votos } \\
\text { Nulos }\end{array}$ & $\begin{array}{l}\text { Qt Votos } \\
\text { Válidos }\end{array}$ \\
\hline BORÁ & 994 & 0 & 0 & 938 & 56 & 0 \\
\hline
\end{tabular}

Somando os votos válidos com os votos em branco, todos do primeiro exemplo, chegase a um total de 938 votos em branco (=922 votos válidos +16 votos em branco).

Assim, considerando que o quociente eleitoral se obtém pela divisão do número de votos válidos pelo número de cargos a ocupar, no caso ele é igual a $0 / 9=0$.

O resultado é absurdo, mas a análise irá prosseguir seguindo os termos literais da lei. Já o quociente partidário é obtido pela divisão do número de votos válidos do partido ou coligação pelo quociente eleitoral. No caso, todos os partidos e coligações teriam o mesmo número de votos válidos, que é 0 (zero). Essa quantidade de votos dividida pelo quociente eleitoral, que é 0 (zero), resulta, em termos matemáticos, em um valor indeterminado, ou seja, na prática, um absurdo leva a outro absurdo.

Talvez, então, para tornar o exemplo factível, suponha-se que tenha havido um único voto válido dado ao candidato Paulo Sergio dos Santos do PSB.

Refazendo os cálculos, o quociente eleitoral corresponderia a 1 dividido por 9, ou seja, 0,11. Como deve ser desprezada a fração, ele seria 0 (zero), gerando novamente o problema para obtenção do quociente partidário, pois a divisão por zero não teria sentido em termos práticos. Então, somente é possível prosseguir com o exemplo se se admitir que houve 9 votos válidos. Como a ideia é trazer um exemplo extremo, pode-se adotar esse número.

Supondo que esses 9 votos tenham sido dados ao candidato Paulo Sergio dos Santos do PSB, os cálculos ficariam assim:

O quociente eleitoral seria 1 , que é o resultado dos 9 votos válidos divididos pelo número de lugares, que é 9.

O quociente partidário do PSB seria 9, que resulta dos seus 9 votos válidos divididos pelo quociente eleitoral, que é 1 . Os demais partidos teriam quociente partidário 0 , resultado de 0 votos válidos dividido por 1.

Então, segundo o art. 108 do Código Eleitoral, serão eleitos tantos candidatos quantos o quociente partidário indicar, ou seja, 9 candidatos do PSB e 0 dos demais.

Com isso, 8 das 9 vagas serão ocupados por candidatos que não receberam nenhum voto. $110^{21}$

Como todos eles estão empatados sem votos, os mais idosos têm preferência pelo art.

Seriam eleitos, então, Paulo Sergio dos Santos, Robson Donley, Domilson Domingos dos Santos, Valdinei Toledo, Silvana de Ben, Adelina Mendes dos Santos, Carlos da Silva, Artur Edson Bregolato e Nadia Angelica Favato Franco. Não será aqui indicada a ordem em que cada um dos candidatos empatados por não se ter acesso fácil às respectivas idades.

\footnotetext{
${ }^{21}$ É importante mencionar que, para aplicar esse dispositivo, o TSE estabelece que: "Res.-TSE no 16.844/1990 e Ac.TSE n os 11.778/1994 e 2.895/2001: no caso de empate na média entre dois ou mais partidos ou coligações, considerar-se-á o partido ou coligação com maior votação, não se aplicando o art. 110 do CE/65. Ac.-TSE ${ }^{\circ}$ 2.845/2001: no caso de empate na média e no número de votos, deve ser usado como terceiro critério de desempate o número de votos nominais." (Brasil. Tribunal Superior Eleitoral. Código eleitoral anotado e legislação complementar. 11. ed. Brasília: Tribunal Superior Eleitoral, Secretaria de Gestão da Informação, 2014, p.68). No caso, essa orientação do TSE não se aplica, permanecendo, então, o critério da idade.
}

Revista de Direito Brasileira | São Paulo, SP | v. 18 | n. 7 | p. 331 - 351 | Set./Dez. 2017 
Aqui, houve alteração significativa no resultado das eleições. De fato, prevaleceu a proporção partidária de representação. Essa representação só é proporcional em relação aos demais partidos, já que o PSB, ao receber 9 votos válidos, possui 9 vezes mais votos do que os demais partidos.

Mas não é de forma alguma proporcional se levar em conta o número de eleitores que votaram em branco.

Além disso, é pouco provável, como se viu, que votos em branco no sistema proporcional impliquem realização de novas eleições.

Uma vez chegado ao extremo nas hipóteses, pode-se continuar a análise agora supondo que os votos em branco ainda fossem válidos.

\subsubsection{Quarto exemplo}

A ideia agora e reapresentar os três exemplos anteriores, mas supondo que os votos em branco ainda fossem válidos.

Em primeiro lugar, haveria mudança no quadro de votação, já que deveriam ser somados os votos brancos aos votos nominais e aos votos em legenda, de modo que $874+48+16=938$.

Quadro de votação:

\begin{tabular}{|l|r|r|r|r|r|r|}
\hline \multicolumn{1}{c|}{ Abrangência } & Qt Comparecimento & $\begin{array}{l}\text { Qt Votos } \\
\text { Nominais }\end{array}$ & $\begin{array}{l}\text { Qt Votos } \\
\text { Legenda }\end{array}$ & $\begin{array}{c}\text { Qt Votos } \\
\text { em Branco }\end{array}$ & $\begin{array}{c}\text { Qt Votos } \\
\text { Nulos }\end{array}$ & \multicolumn{2}{c|}{$\begin{array}{c}\text { Qt Votos } \\
\text { Válidos }\end{array}$} \\
\hline BORÁ & 994 & 874 & 48 & 16 & 56 & 938 \\
\hline
\end{tabular}

O quociente eleitoral passaria a $938 / 9=104,22$, que, desprezando a fração -por ser inferior a 0,5 - resulta 104 .

Por sua vez, os quocientes partidários seriam, para o PSB, 236/104=2,269 ou 2; para a coligação PT/PSD 416/104=4; e para a coligação PTB/PMDB/DEM/PV/PSDB 270/104=2,596 ou 2.

Assim, não houve alteração nos quocientes partidários.

Quocientes eleitoral e partidário:

\begin{tabular}{|c|c|c|c|c|c|c|c|}
\hline UF & Município & $\begin{array}{l}\text { Qt Votos } \\
\text { Válidos }\end{array}$ & $\begin{array}{c}\text { Qt Vagas } \\
\text { QE }\end{array}$ & QE & Legenda & $\begin{array}{c}\text { Qt Votos } \\
\text { Válidos QP }\end{array}$ & $\begin{array}{c}\text { Qt Vagas } \\
\text { QP }\end{array}$ \\
\hline SP & BORÁ & 938 & 9 & 104 & PSB & 236 & 2 \\
\hline SP & BORÁ & 938 & 9 & 104 & PT / PSD & 416 & 4 \\
\hline SP & BORÁ & 938 & 9 & 104 & PTB / PMDB / DEM / PV / PSDB & 270 & 2 \\
\hline
\end{tabular}

Não havendo alteração no quociente partidário e nos votos válidos dos partidos e coligações, o resultado das eleições permaneceria o mesmo.

Como se vê, embora, de fato, o voto em branco, ao ser considerado válido, possa em tese alterar os quocientes, na prática poderá não haver mudanças relevantes.

\subsubsection{Quinto exemplo}

Seguindo a linha de raciocínio, agora será repetido o segundo exemplo, mas com votos em branco sendo considerados válidos.

O objetivo do presente exemplo é ampliar o número de votos em branco, agora, por hipótese, considerados como válidos.

Então, será mantido o número de votos nulos da tabela original, mas os votos nominais de todos os candidatos após José Aprígio dos Santos, do PSDB, serão considerados votos em branco e esses candidatos ficarão com votos zerados. 
Assim, somando os votos dos candidatos com menos votos do que José Aprígio dos Santos, obtêm-se 350 votos, que, somados com os 16 votos em branco originais, resulta 366 votos em branco.

Fazendo isso, obtém-se o seguinte:

Quadro de votação:

\begin{tabular}{|c|c|c|c|c|c|c|}
\hline Abrangência & Qt Comparecimento & $\begin{array}{l}\text { Qt Votos } \\
\text { Nominais }\end{array}$ & $\begin{array}{l}\text { Qt Votos } \\
\text { Legenda }\end{array}$ & $\begin{array}{l}\text { Qt Votos } \\
\text { em Branco }\end{array}$ & $\begin{array}{l}\text { Qt Votos } \\
\text { Nulos }\end{array}$ & $\begin{array}{l}\text { Qt Votos } \\
\text { Válidos }\end{array}$ \\
\hline BORÁ & 994 & 524 & 48 & 366 & 56 & 938 \\
\hline Total Geral & 994 & 524 & 48 & 366 & 56 & 938 \\
\hline
\end{tabular}

Com isso, o PSB fica com 123 votos nominais válidos e mantém 6 votos em sua legenda, totalizando 129 votos. A coligação PT/PSD fica com 291 votos nominais válidos e mantém 26 votos em sua legenda, totalizando 317 votos. A coligação $\mathrm{PTB} / \mathrm{PMDB} / \mathrm{DEM} / \mathrm{PV} / \mathrm{PSDB}$ fica com 110 votos nominais válidos e mantém 16 votos em sua legenda, totalizando 126 votos.

Com 938 votos válidos e 9 lugares para ocupar, o quociente eleitoral é 104.

Quanto ao quociente partidário, tem-se:

PSB: 129 / $104=1,23$, que, sem a fração, fica 1 .

PT/PSD: 317 / 104 = 3,04 que, sem a fração, fica 3.

PTB/PMDB/DEM/PV/PSDB: 126 / 104 = 1,2, que, sem a fração, fica 1.

Quadro de quocientes eleitoral e partidário:

\begin{tabular}{|c|c|c|c|c|c|c|c|}
\hline UF & Município & $\begin{array}{l}\text { Qt Votos } \\
\text { Válidos }\end{array}$ & $\begin{array}{c}\text { Qt Vagas } \\
\text { QE }\end{array}$ & QE & Legenda & $\begin{array}{c}\text { Qt Votos } \\
\text { Válidos QP }\end{array}$ & $\begin{array}{c}\text { Qt Vagas } \\
\text { QP }\end{array}$ \\
\hline SP & BORÁ & 938 & 9 & 104 & PSB & 129 & 1 \\
\hline SP & BORÁ & 938 & 9 & 104 & PT / PSD & 317 & 3 \\
\hline SP & BORÁ & 938 & 9 & 104 & PTB / PMDB / DEM / PV / PSDB & 126 & 1 \\
\hline
\end{tabular}

Usando as regras de distribuição:

O candidato mais votado em Borá foi Paulo Sérgio dos Santos, com 86 votos, do PSB. Ele ocupou, então ele ocupa a única vaga do PSB pelo quociente partidário.

O segundo mais votado, eleito pelo quociente partidário foi Paulo Roberto Gonçalves Gusmão, do PT, com 82 votos, ocupando, então 1 das 3 vagas da coligação PT/PSD.

$\mathrm{O}$ terceiro mais votado foi Wilson Canato, do PT, eleito pelo quociente partidário com 53, ocupando a segunda das 3 vagas da coligação PT/PSD.

O quarto foi Márcio Leovezete, do PSD, com 52 votos, ocupando a última vaga das 3 a que tinha direito a coligação PT/PSD.

O quinto foi Sebastião Carlos Pietro, do PMDB, eleito com 48 votos, ocupando a única vaga da coligação $P T B / P M D B / D E M / P V / P S D B$ pelo quociente partidário.

Embora preenchidos os cargos segundo o quociente partidário, o Município ainda possui 4 vagas de vereador em aberto, já que há 9 cargos e só foram preenchidos 5 cargos. Assim, aplicam-se as regras do art. 109 para preencher essa vaga, ou seja, divide-se o número de votos válidos do partido ou coligação pelo número de lugares obtidos, mais um, de modo que o partido ou coligação com maior média preenche a vaga, repetindo-se o processo até serem preenchidas essas 4 vagas.

Seguindo essa regra, o PSB tem 129 votos válidos, que, divididos por 2, resulta 64,5. A coligação PT/PSD possui 317 votos válidos, que, divididos por 4 , gera 79,25. Por fim, a coligação $P T B / P M D B$ / DEM / $P V / P S D B$ recebeu 126 votos válidos, que divididos por 2

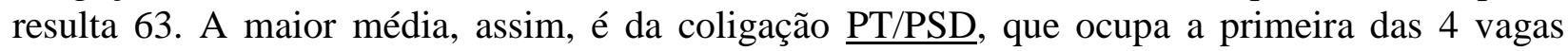
remanescentes, com seu candidato mais votado ainda não eleito, isto é, Edson Alves dos Santos, do PT. 
Para a segunda das 4 vagas das sobras, prosseguindo, o PSB mantém a média 64,5. A coligação PT/PSD possui 317 votos válidos, que, divididos agora por 5, gera 63,4. Por fim, a coligação $P T B / P M D B / D E M / P V / P S D B$ mantém a média 63. A maior média, assim, é do PSB, que ocupa a primeira das 4 vagas remanescentes, com seu candidato mais votado ainda não eleito, isto é, Robson Donley.

Para a terceira das 4 vagas das sobras, prosseguindo, o PSB tem 129 votos válidos, que, divididos agora por 3 , resulta 43. A coligação PT/PSD mantém a média 63,4 e a coligação $P T B / P M D B / D E M / P V / P S D B$ a média 63. A maior média, assim, é da coligação $\underline{\mathrm{PT} / \mathrm{PSD}}$, que ocupa a vaga, com seu candidato mais votado ainda não eleito, isto é, Celso Soares, do PT.

Para a última das sobras, prosseguindo, o PSB manteve a média 43. A coligação

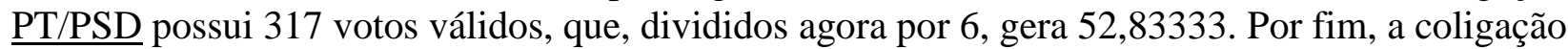
$P T B / P M D B / D E M / P V / P S D B$ mantém a média 63. A maior média, assim, é dessa última coligação, que ocupa a vaga, com seu candidato mais votado ainda não eleito, isto é, Iracema Benedita Ribeiro Vinhando, do DEM.

O resultado fica assim:

\begin{tabular}{l|l|l|l|l|l|l|r|}
\hline UF & Município & \multicolumn{1}{|c|}{ Cargo } & \multicolumn{1}{|c|}{$\mathrm{Nr}$} & \multicolumn{1}{|c|}{ Candidato } & Partido & \multicolumn{1}{|c|}{ Situação } & $\begin{array}{c}\text { Qt Votos } \\
\text { Válidos }\end{array}$ \\
\hline SP & BORÁ & Vereador & 40.650 & PAULO SERGIO DOS SANTOS & PSB & Eleito por QP & 86 \\
\hline SP & BORÁ & Vereador & 13.111 & $\begin{array}{l}\text { PAULO ROBERTO GONÇALVES } \\
\text { GUSMÃO }\end{array}$ & PT & Eleito por QP & 82 \\
\hline SP & BORÁ & Vereador & 13.567 & WILSON CANATO & PT & Eleito por QP & 53 \\
\hline SP & BORÁ & Vereador & 55.650 & MÁRCIO LEOVEZETE & PSD & Eleito por QP & 52 \\
\hline SP & BORÁ & Vereador & 15.100 & SEBASTIÃO CARLOS PIETRO & PMDB & Eleito por QP & 48 \\
\hline SP & BORÁ & Vereador & 13.555 & EDSON ALVES DOS SANTOS & PT & $\begin{array}{l}\text { Eleito por } \\
\text { média }\end{array}$ & 40 \\
\hline SP & BORÁ & Vereador & 40.123 & ROBSON DONLEY & PSB & $\begin{array}{l}\text { Eleito por } \\
\text { média }\end{array}$ & 37 \\
\hline SP & BORÁ & Vereador & 13.620 & CELSO SOARES & PT & $\begin{array}{l}\text { Eleito pela } \\
\text { média }\end{array}$ & 33 \\
\hline SP & BORÁ & Vereador & 13.640 & PEDRO CORREIA DA COSTA & PT & Suplente & 31 \\
\hline SP & BORÁ & Vereador & 25.333 & $\begin{array}{l}\text { IRACEMA BENEDITA RIBEIRO } \\
\text { VINHANDO }\end{array}$ & DEM & $\begin{array}{l}\text { Eleito por } \\
\text { média }\end{array}$ & 31 \\
\hline SP & BORÁ & Vereador & 45.555 & JOSE APRIGIO DOS SANTOS & PSDB & Suplente & 31 \\
\hline
\end{tabular}

Essa tabela, comparada com a tabela do segundo exemplo, também traz algumas diferenças: Edson Alves dos Santos, do PT, e Robson Donley, do PSB, haviam sido eleitos pelo quociente partidário e agora foram eleitos pela média.

\subsubsection{Sexto exemplo}

Finalmente, será replicado aqui o terceiro exemplo, isto é, será aumentado ao máximo o número de votos em branco, mas agora eles serão considerados como válidos.

É mantido, então, o quadro de comparecimento:

\begin{tabular}{|c|c|c|c|c|}
\hline Abrangência & Qt Aptos & Qt Aptos Totalizados & Comparecimento & Abstenção \\
\hline BORÁ & 1.071 & 1.071 & 994 & 77 \\
\hline Total Geral & 1.071 & 1.071 & 994 & 77 \\
\hline
\end{tabular}

Dos que compareceram, todos os seus votos serão considerados como sendo em branco, exceto aqueles que foram nulos: 
Quadro de votação:

\begin{tabular}{|l|r|r|r|r|r|r|}
\hline \multicolumn{1}{|c|}{ Abrangência } & Qt Comparecimento & $\begin{array}{c}\text { Qt Votos } \\
\text { Nominais }\end{array}$ & $\begin{array}{c}\text { Qt Votos } \\
\text { Legenda }\end{array}$ & $\begin{array}{c}\text { Qt Votos } \\
\text { em Branco }\end{array}$ & $\begin{array}{c}\text { Qt Votos } \\
\text { Nulos }\end{array}$ & $\begin{array}{c}\text { Qt Votos } \\
\text { Válidos }\end{array}$ \\
\hline BORÁ & 994 & 0 & 0 & 938 & 56 & 938 \\
\hline
\end{tabular}

A quantidade de cargos de vereador no Município é de 9, que corresponde ao mínimo previsto no art. 29, IV, da Constituição, para Municípios com população até 15.000 habitantes.

Considerando que o quociente eleitoral se obtém pela divisão do número de votos válidos pelo número de cargos a ocupar, no caso ele é igual a 938 / $9=104,2222$. A fração deve ser desprezada, de modo que se chega ao quociente eleitoral de 104.

Já o quociente partidário é obtido pela divisão do número de votos válidos do partido ou coligação pelo quociente eleitoral. No caso, todos os partidos e coligações teriam o mesmo número de votos válidos, que é 0 (zero). Essa quantidade de votos dividida pelo quociente eleitoral, que é 104, resulta 0 (zero).

$\mathrm{O}$ art. 108 do Código Eleitoral determina que serão eleitos tantos candidatos quantos o quociente partidário indicar. O resultado está indicando que nenhum candidato será eleito pelo quociente eleitoral.

Os lugares que não são preenchidos pelo quociente partidário se sujeitam às regras de destruição do art. 109 do Código Eleitoral. De acordo com ele, a primeira das vagas remanescentes será concedida à coligação ou partido com maior média, segundo os critérios já tratados.

O $\S 2^{\circ}$ do art. 109, porém, prevê que somente pode concorrer a essa distribuição pelo critério da média os partidos e coligações que tenham obtido quociente eleitoral. No caso, como se vê, nenhum partido ou coligação alcançou o quociente eleitoral. Aliás, não tiveram voto algum.

Segue-se, então, para a regra do art. 111 do Código Eleitoral, segundo a qual os candidatos mais votados serão eleitos em caso de nenhum partido ou coligação alcançar o quociente eleitoral.

Duas interpretações cabem aqui. A primeira é a de que todos os candidatos têm o mesmo número de votos, de modo que seriam eleitos segundo os critérios de desempate. A segunda pode considerar que a regra do art. 111 só é aplicável a candidatos que tenham conseguido votos.

Talvez a segunda seja a mais adequada, de modo que a solução seria realizar novas eleições, aplicando-se o art. 113, ainda que por analogia.

Portanto, se quase todos os votos fossem em branco e se eles fossem válidos, seria necessário realizar novas eleições.

\subsubsection{Conclusões sobre o voto em branco e o voto nulo nas eleições proporcionais}

Do quadro exposto, em relação aos votos em branco, o fato de deixarem de ser válidos tornou mais fácil atingir o quociente eleitoral, pois o dividendo (número total de votos válidos) diminuiu. Fica evidente, então, a possibilidade de alterar também o quociente partidário e, portanto, o resultado das eleições.

Se o número de votos válidos aumenta isso significa que o quociente eleitoral irá reduzir, já que o número de vagas a preencher permanece inalterado.

Conforme diminui o quociente eleitoral, o quociente partidário aumenta, considerando que este último resulta da divisão do número de votos válidos dados ao partido pelo primeiro.

A alteração da situação de eleito pelo quociente partidário para eleito pela média não traz repercussões importantes. 
Já no segundo exemplo, um aumento significativo do número de votos em branco provocou a mudança de eleito para suplente e vice-versa para dois candidatos. Considerando um universo de 9 vagas, a alteração da situação de 2 candidatos representa uma grandeza de $22 \%$.

Segundo o $\$ 2^{\circ}$ do art. 109 , somente podem concorrer à distribuição de lugares os partidos ou coligações que tiverem obtido quociente eleitoral, isto é, somando-se os votos nominais dos candidatos do partido ou coligação, com os votos na legenda, deve haver um número no mínimo igual ao quociente eleitoral.

O quociente eleitoral é obtido pela divisão dos votos válidos pelo número de lugares a ocupar no órgão legislativo. No caso de Borá/SP, tendo 9 lugares em sua Câmara Municipal, é certo que somente partidos ou coligações com pelo menos 9 votos válidos poderão concorrer à distribuição de lugares.

Então se houver, por exemplo, do total de votos de Borá, apenas 9 votos válidos para 9 candidatos do PSB, com um voto para cada um, somente este partido concorrerá à distribuição. Isso foi visto no terceiro exemplo.

Se os votos em branco ainda fossem considerados válidos, seu número expressivo teria mais possibilidade de ensejar novas eleições, como se viu no sexto exemplo.

Enfim, para que os votos em branco e nulos alterem o resultado das eleições, seu número deve ser expressivo, mas isso se mostra bem improvável na prática. Para que haja novas eleições, seus valores devem chegar ao extremo.

\section{O VOTO EM BRANCO E O VOTO NULO NAS REGRAS DAS ELEIÇÕES MAJORITÁRIAS}

Nas eleições majoritárias, a situação muda um pouco.

Sobre as eleições presidenciais, a Constituição Federal prevê:

Art. 77. A eleição do Presidente e do Vice-Presidente da República realizar-se-á, simultaneamente, no primeiro domingo de outubro, em primeiro turno, e no último domingo de outubro, em segundo turno, se houver, do ano anterior ao do término do mandato presidencial vigente. (Redação da EC 16/1997)

$\S 1^{\circ}$ - A eleição do Presidente da República importará a do Vice-Presidente com ele registrado.

$\S 2^{\circ}$ - Será considerado eleito Presidente o candidato que, registrado por partido político, obtiver a maioria absoluta de votos, não computados os em branco e os nulos.

$\S 3^{\circ}$ - Se nenhum candidato alcançar maioria absoluta na primeira votação, farse-á nova eleição em até vinte dias após a proclamação do resultado, concorrendo os dois candidatos mais votados e considerando-se eleito aquele que obtiver a maioria dos votos válidos.

$\S 4^{\circ}$ - Se, antes de realizado o segundo turno, ocorrer morte, desistência ou impedimento legal de candidato, convocar-se-á, dentre os remanescentes, o de maior votação.

$\S 5^{\circ}$ - Se, na hipótese dos parágrafos anteriores, remanescer, em segundo lugar, mais de um candidato com a mesma votação, qualificar-se-á o mais idoso. ${ }^{22}$

\footnotetext{
22 Para Governadores, esse dispositivo também é observado: “Art. 28. A eleição do Governador e do ViceGovernador de Estado, para mandato de quatro anos, realizar-se-á no primeiro domingo de outubro, em primeiro turno, e no último domingo de outubro, em segundo turno, se houver, do ano anterior ao do término do mandato de seus antecessores, e a posse ocorrerá em primeiro de janeiro do ano subsequente, observado, quanto ao mais, o disposto no art. 77.(Redação dada pela Emenda Constitucional no 16, de1997)" Para eleição de Prefeito, essas mesmas regras se aplicam se o Município tiver mais de duzentos mil habitantes: "Art. 29. O Município reger-se-á por lei orgânica, votada em dois turnos, com o interstício mínimo de dez dias, e aprovada por dois terços dos membros da Câmara Municipal, que a promulgará, atendidos os princípios estabelecidos nesta Constituição, na
}

Revista de Direito Brasileira | São Paulo, SP | v. 18 | n. 7 | p. 331 - 351 |Set./Dez. 2017 
De acordo com esse dispositivo, os votos em branco e os nulos, no primeiro turno, não são considerados. Descontando-se esses votos, será eleito quem conseguir maioria absoluta dos demais votos.

Se ninguém alcançar a maioria absoluta, é necessário um novo turno. No segundo turno, apenas os dois candidatos mais votados concorrem, sendo eleito o que obtiver a maioria dos votos válidos. Aqui, então, os votos brancos são computados, porém, a maioria agora é simples, não mais absoluta ${ }^{23}$.

No primeiro turno, votos em branco e votos nulos não contam (WALDSCHMIDT, 2014). Imaginando que todos os brasileiros utilizassem um desses dois votos, com exceção de um eleitor, que votasse em um candidato, esse candidato seria eleito com 100\% dos votos válidos.

Se houvesse dois candidatos, cada um com 1 voto, haveria segundo turno. Se, no segundo turno, eles se mantivessem empatados, ainda assim, haveria um eleito, o mais idoso.

Ainda que essa interpretação seja válida, isso é inconcebível na prática.

\section{REFLEXÕES CRÍTICAS}

De acordo com o que foi exposto, o eleitor parece não ter, na prática, opção de negar os candidatos. Nesse aspecto, o passageiro do avião citado no início do texto está melhor do que ele. Ainda que o eleitor tenha mais opções do que o passageiro, todas são opções "sim”.

Se o eleitor não quiser ninguém, não terá instrumento algum com eficiência para negar os candidatos.

Alguém poderia objetar que isso levaria à possibilidade de ninguém ser eleito e o país ficar sem representante. Mas isso é difícil, pois a CF prevê mecanismos para tanto, pelo menos com o Executivo, ao estabelecer uma ordem de sucessão, podendo o cargo de presidente vir a ser ocupado provisoriamente até mesmo por um membro do Poder Judiciário. No legislativo, dificilmente a casa ficará vazia. Mesmo que fique, é possível aguardar assim até que novas eleições sejam realizadas. Com efeito, uma coisa é a urgência requerida para as medidas que o Executivo tem que tomar na prestação do serviço público. Outra é a situação do legislativo, em que diplomas legislativos demoram até anos para serem editados. Mesmo a Lei Orçamentária,

Constituição do respectivo Estado e os seguintes preceitos: [...] II - eleição do Prefeito e do Vice-Prefeito realizada no primeiro domingo de outubro do ano anterior ao término do mandato dos que devam suceder, aplicadas as regras do art. 77, no caso de Municípios com mais de duzentos mil eleitores;(Redação dada pela Emenda Constitucional $\mathrm{n}^{\mathbf{0}}$ 16, de1997)"

${ }^{23}$ Sobre esse dispositivo já se pronunciou o STF: “Cálculo do quociente eleitoral. Votos brancos. Inclusão. Art. 106, parágrafo único, do Código Eleitoral. Alegada ofensa aos arts. $77, \S 1^{\circ} ; 32, \S 3^{\circ}$, e 45 , caput, da $\mathrm{CF}$, e ao art. $5^{\circ}$ do ADCT. Improcedência da arguição. Os votos brancos também representam manifestação da vontade política do eleitor. São eles computados em eleições majoritárias em face de norma expressa (arts. 28; 29, II; e 77, § 2º da CF) configuradora de exceção alusiva às eleições majoritárias, não podendo por isso ser tomada como princípio geral. $\mathrm{O}$ art. $5^{\circ}$ do ADCT limitou-se a dispor sobre a inaplicabilidade, à eleição para Prefeito nele referida, do princípio da maioria absoluta previsto no $\S 2^{\circ}$ do referido art. 77 do texto constitucional permanente, não dispondo sobre voto em branco.” (RE 140.460, Rel. Min. Ilmar Galvão, julgamento em 19-5-1993, Plenário, DJ de 4-5-2001.) “Eleições majoritárias: nulidade: maioria de votos nulos, como tais entendidos os dados a candidatos cujo registro fora indeferido: incidência do art. 224 do Código Eleitoral, recebido pela Constituição. $\mathrm{O}$ art. 77 , § 2º da CF, ao definir a maioria absoluta, trata de estabelecer critério para a proclamação do eleito, no primeiro turno das eleições majoritárias a ela sujeitas; mas, é óbvio, não se cogita de proclamação de resultado eleitoral antes de verificada a validade das eleições; e sobre a validade da eleição - pressuposto da proclamação do seu resultado, é que versa o art. 224 do Código Eleitoral, ao reclamar, sob pena da renovação do pleito, que a maioria absoluta dos votos não seja de votos nulos; as duas normas - de cuja compatibilidade se questiona - regem, pois, dois momentos lógica e juridicamente inconfundíveis da apuração do processo eleitoral; ora, pressuposto do conflito material de normas é a identidade ou a superposição, ainda que parcial, do seu objeto normativo: preceitos que regem matérias diversas não entram em conflito." (RMS 23.234, Rel. Min. Sepúlveda Pertence, julgamento em 2-10-1998, Primeira Turma, DJ de 20-11-1998.) 
que deveria ser votada anualmente, costuma atrasar, obrigando o Executivo a recorrer a medidas normalmente previstas na Lei de Diretrizes Orçamentárias. Para medidas urgentes, o Executivo ainda pode editar Medidas Provisórias, observadas obviamente certas restrições.

Se mesmo em Borá/SP, que é o menor Município brasileiro, houve votação expressiva nominal, não se acredita que seja factível haver uma hipótese em que não haveria candidatos.

Alguma coisa não anda bem.

Quanto ao significado do voto nulo e do voto em branco, DANTAS NETO traz a seguinte citação, que merece ser comentada ${ }^{24}$ :

O voto nulo pode ser entendido como "ausência de voto, renúncia ao direito de preferência, o voto nulo é, nesses termos, um voto positivo, no sentido em que, como o voto em um candidato ou em um partido, ele representa uma manifestação da vontade eleitoral. Condenatória, mas sempre vontade afirmativa. Pois é por seu intermédio que o cidadão expressa sua condenação às limitações do pleito. O voto em branco é de quem cala; o voto nulo é de quem fala, protestando. Daquele que, particularmente nas rodadas de segundo turno, não se vê contemplado pelas candidaturas em disputa. $\mathrm{O}$ voto nulo, aliás, interfere no resultado do pleito, porque pode anulá-lo, como vimos anteriormente. Mas o voto nulo também pode resultar de ausência de vontade, quando é o voto do erro, do que não soube votar corretamente" (MANUAL DAS ELEIÇÕES. Roberto Amaral, Sérgio Sérvulo da Cunha. $4^{a}$ edição - São Paulo: Saraiva, 2010. p. 89).

Em relação a essas afirmações, é bom lembrar que uma coisa é o que diz a lei. Outra é a intenção do eleitor. A lei diz que o voto nulo não vale. Diz que o voto em branco às vezes conta.

A intenção do eleitor, por outro lado, ao votar em branco ou ao anular seu voto, pode ser a mais variada possível. Pode querer protestar, pode errar no momento de votar, pode votar em um candidato apenas para outro não ganhar e pode querer se abster, concordando com o resultado que vier.

Falta, porém, um instrumento de efetiva negação. Algo com o qual o eleitor diga que não quer o candidato lá presente.

Mesmo as pesquisas de opinião, atualmente, fazem questionamentos para apurar a rejeição dos candidatos.

Algo que parece um grande contrassenso é o fato de obrigar o eleitor a votar. Como pode a Constituição obrigar o eleitor a votar e depois não contar esse voto quando ele é em branco ou nulo? O que é obrigatório, então, não é o voto, mas o comparecimento. Seria melhor que não obrigasse a votar - e nem a comparecer, obviamente.

Então, a única conclusão a que pode se chegar é a seguinte: se o eleitor não estiver satisfeito com os candidatos que lá estão, a única alternativa é se candidatar ou tomar medidas para que bons candidatos se registrem para participar das eleições.

Não há espaço vazio. Se o bem se omite, o mal domina.

E Dante, na Divina Comédia, lembra que o lugar dos omissos é na antecâmara do inferno, nele não entrando e nem sendo aceitos no céu.

\section{CONCLUSÃO}

Como se viu no decorrer do texto, atualmente, nas eleições proporcionais, os votos brancos e nulos são equivalentes, sendo ambos desconsiderados nas contagens.

\footnotetext{
${ }^{24}$ DANTAS NETO, Afonso Tavares. Voto nulo e anulação da eleição. In: Âmbito Jurídico, Rio Grande, XV, n. 106, nov. 2012. Disponível em: <http://ambito-juridico.com.br/site/?n_link=revista_artigos _leitura\&artigo_id=12483\&revista_caderno=28>. Acesso em jun. 2014.
} 
Nas eleições majoritárias para o executivo, os votos em branco e os nulos não são computados no primeiro turno. Já no segundo turno, os votos em branco são computados.

Porém, em ambas, a repercussão desses votos, em termos práticos, não parece relevante. Seria necessário levar ao extremo o número de votos em branco ou nulos para que houvesse algum efeito sério, como a necessidade de novas eleições.

As eleições então são um cardápio fechado, sem possibilidade de modificação e sem possibilidade de negação. É como se alguém fosse obrigado a ir a um restaurante e escolher um item do cardápio. Mesmo que não quisesse nenhum dos itens, um prato lhe seria servido obrigatoriamente.

Se votos em branco e votos nulos não são considerados, então não se vê razão para obrigar um eleitor a ir até a urna de votação.

\section{REFERÊNCIAS BIBLIOGRÁFICAS}

BARROS, Francisco Dirceu. Resumo de direito eleitoral. 5.ed. Rio de Janeiro: Elsevier, 2010.

BRASIL. Tribunal Superior Eleitoral. Código eleitoral anotado e legislação complementar. 11. ed. Brasília: Tribunal Superior Eleitoral, Secretaria de Gestão da Informação, 2014.

BRASIL. Diário Da Câmara Dos Deputados, Ano LII, nº 170, Brasília, DF, 24.set.1997.

BRASIL. Lei $\mathrm{n}^{\circ}$ 9.504, de 30 de setembro de 1997. Estabelece normas para as eleições. Planalto.gov.br. Disponível em: <http://www.planalto.gov.br/ccivil_03/leis/19504.htm> Acesso em: 8.ago.2014.

BRASIL. Lei no 4.737, de 15 de julho de 1965. Institui o código eleitoral. Planalto.gov.br. Disponível em: <http://www.planalto.gov.br/ccivil_03/leis/14737.htm> Acesso em: 6.ago.2014.

CÂNDIDO, Joel J.. Direito eleitoral brasileiro. 13. ed. Bauru, SP: Edipro, 2008.

CUNHA, Sérgio Sérvulo da. Dicionário compacto do direito. 2.ed. São Paulo: Saraiva, 2003.

DANTAS NETO, Afonso Tavares. Voto nulo e anulação da eleição. In: Âmbito Jurídico, Rio Grande, XV, n. 106, nov. 2012. Disponível em: <http://ambitojuridico.com.br/site/?n_link=revista_artigos_leitura\&artigo_id=12483\&revista_caderno=28>. Acesso em jun. 2014.

FERREIRA, PINTO. Código eleitoral comentado. 3.ed. São Paulo: Saraiva, 1991.

MELLO, Marcos Bernardes de. Teoria do fato jurídico: plano da validade. 6.ed. São Paulo: Saraiva, 2004.

'PUXADORES' de votos: candidatos que conseguem eleger a legenda. Acrítica. Manaus 4.mai.2014. Disponível em: <http://acritica.uol.com.br/noticias/Puxadores-candidatosconseguem-eleger-legenda_0_1132086784.html> Acesso em: 5.jun.2014. 
ROLLO, Alberto. Candidato do Prona é eleito mesmo sem nenhum voto. Consultor Jurídico. 7.out.2002. Disponível em: <http://www.conjur.com.br/2002-out07/candidato_prona_eleito_mesmo_nenhum_voto> Acesso em: 5.6.2014.

WALDSCHMIDT, Hardy. Prefeito: candidatura única e número mínimo de votos. Disponível em: <http://www.tse.jus.br/arquivos/tre-ms-artigo-prefeito-candidatura-unica-e-numero-minimode-votos> Acesso em: 13.jun.2014. 